\title{
POLITENESS PRINCIPLE ANALYSIS IN CARTOON MOVIE ENTITLED STAND B Y ME DORAEMON
}

\author{
Eko Mulyono \\ Muhammadiyah University of Surakarta \\ ekomulyono588@gmail.com
}

\begin{abstract}
This article examines the use of politeness principle in cartoon movie entitled "Stand By Me Doraemon". It aims at giving a description on the use of politeness principle in this movie so that this is the source of data as well. The data are collected by note taking technique and then analyzed descriptively. After analyzing the data, the researcher finds the use of politeness principle in the movie script. They are utterances of the use of politeness principle covering the kinds of maxim in politeness principle. The utterances covey the use of tact maxim, generosity maxim, approbation maxim, modesty maxim, agreement maxim, and sympathy maxim. Then, it focused also in politeness scale such as formality scale, hesitancy scale, and equality scale. The finding result showed that there are 25 politeness principle found in cartoon movie "Stand By Me Doraemon". 1 tact maxim, 3 generosity maxim, 6 approbation maxim, 1 modesty maxim, 2 agreement maxim, 3 sy mpathy maxim, 2 formality scale, 4 hesitancy scale, and 3 equality scale. Approbation maxim is the maxim of the most numerous in the movie. This is because the characters in this film seek to avoid conflict and create an environment that is comfortable in communication.
\end{abstract}

Key words: politeness principle, cartoon movie, utterance, maxim, scale.

\section{INTRODUCTION}

As it is commonly, language is a system of arbitrary vocal symbols used for human communication (Wardhaugh, 1977: 3). It means that language is a medium to deliver an idea or felling. By using language human being can communicate information and maintain relationship among members of a speech community. In communicating ideas and information to listeners, a speaker must pay a serious attention to the setting of the conversation. A field of linguistics which concern so much on this phenomena is called pragmatics.

Parker (1986) in Wijana (1996: 2) states that pragmatics is distinct from grammar, which is the study of internal structure of language. Pragmatics is the study of how language is used to communicate. It means that pragmatics is not the study about language grammar, but it is the study of language in communication which depends so much in context.

In relation to pragmatics, Leech (1983: 10) states that "Pragmatics can be usefully defined as the study of how utterances have meaning in situation". Without neglecting the 
definition of pragmatics given by Leech, it can be seen that pragmatics is a study which tries to understand meaning of utterances by looking at the situation when the utterances happens. Pragmatics talks about the meaning of expressions. While, according to Levinson (1983:24), pragmatics is the study of ability of language users to pair sentences with the contexts in which they would be appropriate. Based on the statements above, pragmatics can be defined as the study of speaker's meaning. The speaker and the hearer can use their background knowledge to easily understand every utterance they produce.

According to Yule (1996) Politeness is defined as the means employed to show awareness of another person's face, the public self-image of a person. In other words, it is satisfying the face wants of other people. It also describes the extent to which somebody's actions (and his words) match other's perceptions of how they should be performed (Grundy, 1995) and can be accomplished in situations of social distance or closeness. The kind of politeness shown by a person who shows awareness of another person's face (when that other appears socially distant) is "described to be of respect and deference, while politeness shown by a person to another person when that other is socially close is described in terms of friendliness, camaraderie, or solidarity“(Yule, 1996).

The variety of educational technology offers language teachers more opportunities when they select materials as multimedia or electronic to teach students the target language in the classroom (Tsai, 2011 in http://www.ukessays.com/essays/english-language/the-effects-ofusing-cartoon videos-english-language-essay.php?cref=1). Cartoon movies with subtitles are kind of useful and important audiovisual materials in teaching/ learning the second language. According to Wyk, (2011) in http://www.ukessays.com/essays/english-language/the-effectsof-using-cartoon-videos-english-language-essay.php?cref=1 cartoons videos have supposed a potentially valuable contribution in teaching and they have visually impacted all students immediately without discrimination of age or background, are able to respond in some way to the educational point being made. Indeed, Cartoon movies with subtitles are kind of useful and important audiovisual materials in teaching/ learning the second language.

Titi (2007) explains that a cartoon movie is moving diagrams or cartoon that are made up of a sequence of images displayed one after the other. Moreover, she add other referent that a cartoon movie is the illusion of motion created by the consecutive display of images of static elements. Technology is used to make them become more interesting as the result of development of peoples imagination.

In addition, Pande (2008) explains that a cartoon movie is an exaggerated amusing illustration caricaturing in moving diagram way of criticizing a person or event with some 
thoughts. A cartoon movie is a special form of art to present amusing appearance with the help of colorful moving diagram exaggerated. In short, it can be seen in cartoon movie how to shown people's imagination that is revealed in drawing forms. By using cartoon movie people can learn everything like human, social and animal behavior. All of those are packed in a motion pictures and effects.

Utterances can be found in conversation between two persons, one is a speaker and the other is a hearer. In this research the researcher focuses the research in cartoon movie conversation. One of the cartoon movie worth studying is Stand By Me Doraemon. This movie is then analyzed pragmatically focusing on the use of politeness principles covering every maxim and scale by Leech and Lakoff. Hopefully, this study can not only provide information on the use of one principle in pragmatic studies but also teach the readers on how to implement the politeness principles in communication.

\section{REVIEW OF RELATED LITERATURES}

\section{Previous Research Overview}

Ismet (2014) entitled Aspek Sopan Santun Ujaran Dalam Film Eat Pray Love Karya Ryan Murphy. The study attempts to identify and analyze the politeness aspects which are found in the film Eat Pray Love. In the research, the writer focuses on the polite utterance as one aspect of behavior which is found in the film Eat Pray Love. The research was done through the descriptive method. In collecting the data, the writer paid close attention to the available relevant data through conversation among the characters in the film. Then the writer categorized them into their suitable maxims using the concept of Leech. The finding shows that the uses of politeness maxims in the film are tact maxim, generosity maxim, approbation maxim, modesty maxim, agreement maxim, and sympathy maximthe reseach expected that it can help the students and readers in learning politeness aspects of using language.

Setyaningsih (2007) entitled "An analysis of positive politeness Strategy in the film entitled "in good company". The research conducted to find out the kinds of the positive politeness strategies employed by the characters and the factors influencing the characters to employ those strategies in relation to Brown and Levinson's politeness strategy. The research deals with Pragmatics approach. It is a descriptive qualitative study, and it employs purposive sampling as the sampling technique. The data are all the dialogs containing positive politeness strategy which have significant relationship with the problem statements. There are 29 data found in the film. The data are then identified by using Brown and Levinson's 
politeness strategy to answer the kinds of positive politeness strategy employed by the character. The result of the analysis shows that there are 15 strategies of positive politeness employed by the characters in the dialogs of film entitled "In Good Company". Among them are notice, attend to the hearer (4 data), exaggerate ( 1 datum), intensify interest to the hearer (1 datum), use in-group identity markers (4 data), seek agreement (1 datum), avoid disagreement (5 data), presuppose / raise / assert common ground (2 data), joke (4 data), assert or presuppose the speaker's knowledge and concern for the hearer's wants (1 datum), offer / promise (1 datum), be optimistic (1datum), includes both the speaker and the hearer (1 datum), give (or ask for) reasons (2 data), assume or assert reciprocity (1data) and give gifts to the hearer (1datum). Thus, all kinds of positive politeness strategies are employed by the characters.

Sinkeviciute (2010) entitled "A Comparative Analysis of Politeness in First Encounter Conversations in British English Film and Peninsular Spanish Film”. The paper analyzed the Politeness in First Encounter Conversations in British English Film and Peninsular Spanish Film. The data from the analysis were taken by film Love Actually (British English) film $\mathrm{Va}$ A Ser Que Nadie Es Perfecto (Peninsular Spanish) which were analyzed applying Brown and Levinson framework. The result shows the positive politeness in Spanish and negative politeness in British English film.

Handayani (2011) entitled "The analysis of politeness strategies used by the characters in the film of Ugly Truth". The research was conducted to distinguish politeness strategies used by selected characters in the film. The researcher used qualitative method to get the data. Then, the finding showed that the factor of higher and lower in workplace is not one of the main factors that can cause the different politeness strategy. However, the lower character has the same strategy as the higher did.

Krisnoni (2013) entitled "Politeness Strategies used in Request by the Characters in Inception Movie”. Request is the most common speech act used by people to ask someone to do something. Intrinsically request is a face threatening act which commonly put threats on requestee's negative face. The paper investigates the politeness strategies involved in the requests found in Inception movie. The research is a descriptive qualitative method. The data of the research are the excerpts of conversation which are produced by all the characters with the other containing request strategy in Inception movie. The politeness is used by the characters of the movie is analyzed using politeness strategies proposed by Brown and Levinson (1987). The result of the study show that The greatest amount of politeness strategy which is used by all the characters is bald-on record that is 72 cases. 
Nikmah (2012) entitled "Analysis of Apology As A Politeness Style of Expressed By The Characters In The Twilight Saga Movie”. The research is based on the Pragmatics study. Aims of the research are to find out the types of apology expressions, the strategy of apology, types of politeness strategy and why each type of apology as politeness strategy is employed by characters in "Twilight" movie. The research employs a descriptive qualitative method. In classifying the types of apology as politeness strategy, the writer uses Yule, Levinson and Austin, Olstain and Cohen theory. There are 22 apologizing expressions in the analysis. They are divided into two types of apologizing expressions. They are direct and direct apology. There are three strategies of apology in the analysis. They are an expression of regret, an offer of apology, an explanation. The researcher finds two types politeness strategy, they are positive politeness and negative politeness.

Based on those previous researches, this research focuses on the politeness principle analysis in cartoon movie entitled Stand by Me Doraemon. The research will be conducted to find the politeness principle such as kinds of maxim and politeness scale in the movie conversation.

\section{The Notion of Politeness Principle}

Politeness principle is minimizing (all thing being equal) the expression of impolite beliefs; maximizing (all things being equal) the expression of polite beliefs (Thomas, 1995: 159). While Leech (1983: 132) states that politeness concerns a relationship between two participants; self and other. Self has to be more polite in referring to other's spouse that in referring to self's own spouse.

According to Yule (1996: 60), politeness can be defined as the means employed to show awareness of another person's face. In other hand, politeness can be accomplished in situations of social distance or closeness. For example, in following illustrations the first type might be found in a student's question to the teacher (I.a), second illustration in the friend's question to the same individual (I.b)

(I) a Excuse me, Mr Buckingham, but can I talk to you for a minute? b Hey, Bucky got a minute?

Concerning the above utterances, it can be understood that that there will be different kinds of politeness with the assumption of relative social distance or closeness. In most English speaking context, the participants in an interaction often have to determine as they speak, the relative social distance between them and hence their face wants.

Further, Yule (1996: 62) states two faces, they are: 
a. Negative politeness is a face saving act which is oriented to the person's negative face which will tend to show difference, emphasize the importance of the other's time or concerns, and even include an apology for the imposition or interruption.

Example:

(1) How about letting me use your pen?

(2) Hey, buddy, I'd appreciate it if you'd let me use your pen.

b. Positive politeness is a face saving act which concerned with the person's positive face. It will tend to show solidarity, emphasize that both speakers want the same thing, and they have a common goal.

Example:

(1) Could you lend me a pen?

(2) I'm sorry to bother you, but can I ask you for a pen or out something?

(3) I know you're busy, but might I ask you if - em - if you happen to have an extra pen that I could, you know - eh - maybe borrow.

\section{Maxims of Politeness Principle}

According to Leech (1983: 132) the maxim of Politeness Principle tends to go in pairs as follows.

a. Tact maxim

In the tact maxim a speaker minimizes the expression of beliefs which imply cost to other; maximizes the expression of beliefs which imply benefit to other.

Example:

David : Oh, hi Nancy! Look at you! How wonderful you are!

Nancy : Thank you. You look great, too.

In the utterance David maximizes benefit to Nancy by praising Nancy about her beauty. Meanwhile, Nancy also maximizes David by giving responds about his self.

b. Generosity maxim

In the generosity maxim a speaker minimizes the expression of beliefs that express or imply benefit to self; maximizes the expression of beliefs that express or imply cost to self. Unlike the tact maxim, the maxim of generosity focuses on the speaker, and says that others should be put first instead of the self.

Example:

(1) I can lend you my car

(2) You must come and have dinner with us. 
In utterance (1), the speaker maximizes benefit to the hearer by offering him to lend his car, although he adds burden for himself. In utterance (2), the speaker maximizes benefit to the hearer by offering them to come and have dinner with him, although he adds burden for himself.

\section{c. Approbation maxim}

In the approbation maxim a speaker minimizes the expression of beliefs which express dispraise of other; maximizes the expression of beliefs which express approval of other. It is preferred to praise others and if this is impossible, to sidestep the issue, to give some sort of minimal response (possibly through the use of euphemisms), or to remain silent.

Example:

(1) What a marvelous meal you cooked!

(2) That's a nice haircut you got, where did you get it!

It is clearly seen that in utterance (1), the speaker appreciates the meal which have been cooked so much. In utterances (2), the speaker appreciates the hairs which have been cut so much.

d. Modesty maxim

Modesty maxim is a maxim in which a speaker minimizes the expression of praise of self; maximizes the expression of dispraise of self.

Example:

(1) Please accept this small gift as a taken of our esteem

(2) How stupid of me!

In utterance (1), the speaker minimizes self-praise by saying the small gift to the hearer, not large gift. In utterance (2), the speaker maximize self-dispraise by saying that he or she is stupid.

e. Agreement maxim

In the agreement maxim, a speaker minimizes the expression of disagreement between self and other; maximizes the expression of agreement between self and other.

Example:

(1) A: A referendum will satisfy everybody.

B: Yes, definitely.

(2) A: It was an interesting exhibition, wasn't it?

B: No, it was very uninteresting

(3) A: The book is tremendously well written.

B: Yes, well written as a whole, but there are some rather boring patches. 
Utterance B in dialog (1) is more polite than utterance B in dialog (2) because in (2), the hearer maximizes his disagreement. Utterance B in dialog (3) shows his disagreement is often preferable to complete disagreement.

f. Sympathy maxim

Sympathy maxim is a maxim in which a speaker minimizes antipathy between self and other; maximizes sympathy between self and other. This includes a small group of speech acts such as congratulation, commiseration, and expressing condolences.

Example:

I m terribly sorry to hear that your cat died

In utterance above the speaker shows his condolences (as an expression of sympathy for misfortune) her cat died.

\section{Politeness Scale}

There are three kinds of politeness scale, they are; 1) politeness scale of Leech, 2) politeness scale of Brown and Levinson, and 3) politeness scale of Robin Lakoff (Rahardi, 2005: 66-70).

\section{a. Politeness Scale of Leech}

Leech (1983: 123) proposes pragmatic scales which can be used to measure the politeness of a speech. They are:

1) Cost benefit scale: Representing the cost or benefit of an act to speaker and hearer. It refers to the cost or benefit of a speech uttered by a speaker. It is stated if a speaker minimizes the benefit from himself, he will be conveyed as a polite speaker. In other words, if an utterance maximizes the benefit of the hearer, it is regarded as a polite utterance.

2) Optimality scale: Indicating the degree of choice permitted to speaker and/or hearer by a specific linguistic act. Optionality scale refers to the number of options uttered by a speaker to a hearer. The more options the speaker and hearer can choose, the more polite the utterances will be.

3) Indirectness scale: indicating the amount of inference required of the hearer in order to establish the intended speaker meaning. Indirectness scale refers to whether an utterance 
is uttered directly or indirectly. The indirect utterances are regarded as polite ones. In other words, the more indirect an utterance is, the more polite it will be.

4) Authority scale: representing the status relationship between speaker and hearer. Authority scale refers to different rank rating between a speaker and a hearer. A quite different rank rating between a speaker and a hearer will cause a more polite utterance uttered.

5) Social distance scale: Indicating the degree of familiarity between speaker and hearer. Social distance scale refers to levels of social relationship between a speaker and a hearer in a conversation. The closer social relationship between a speaker and a hearer influences them to apply a polite utterance.

\section{b. Politeness scale of Brown and Levinson}

There are three kinds of politeness scale of utterance. Each scale is based on contextual, social, and cultural setting (Brown and Levinson, 1987 in Rahardi, 2005: 68-70).

\section{1) Social distance between speaker and hearer}

Social distance scale is determined by different age, sex, and sociocultural background. Older speaker and hearer tend to apply more polite utterances in conversation. On the other hand, younger speaker and hearer tend to apply less polite utterances in conversation. In relation to sex, female speaker and hearer tend to use higher politeness than male ones. Sociocultural background plays a crucial role in determining scale of politeness. Different speakers and hearers coming from different sociocultural backgrounds color different scales of politeness.

\section{2) The speaker and hearer relative power}

The speaker and hearer relative power refers to different positions between a speaker and hearer. In a hospital, a patient has different position from a doctor. In a campus, a student has different position from a lecturer.

\section{3) The degree of imposition associated with the required expenditure of goods or services}

This scale refers to the degree of position between a certain utterance and other utterances. In a certain case, a male quest coming to a female one is regarded as uncommon if he comes at an inappropriate time. In different case, however, this is appropriate. 


\section{c. Politeness Scale of Robin Lakoff}

Lakoff (1973) in Rahardi (2005: 70) states that there are three kinds of politeness scale as follows.

\section{1) Formality scale}

Formality scale refers to a situation stating that a speaker should not force the hearer in a conversation.

\section{2) Hesitancy scale}

This can also be called optionality scale referring to a situation in which a speaker and hearer must feel convenient in a conversation. A speaker should provide options to a hearer so that the situation of a conversation is enjoyable.

\section{3) Equality scale}

This scale refers to the fact that a speaker and a hearer should maintain equality. A speaker should consider that a hearer is his partner.

Based on those explanation above, this research will focus the research in the maxim in politeness principle by Leech and politeness scale by Lakoff.

\section{FINDING AND DISCUSSION}

In this part, the researcher wants to analyze the data collected from cartoon movie of Stand By Me Doraemon. Based on the data, the researcher can find out the description of the object being researched. This research presents clear description of politeness utterance analysis used in cartoon movie of Stand by Me Doraemon which would be presented and analyzed below.

\section{Politeness Principle}

In this research paper, the researcher finds the use of tact maxim, generosity maxim, approbation maxim, modesty maxim, agreement maxim and sympathy maxim.

\section{a. $\quad$ Tact maxim}

In this maxim participants are expected to be humble by reducing the praise of himself. The utterances of tact maxim found in the folklore are as follows:

1. Noby : do you have tool for making Shizuka love to me? 
In this utterance means that Noby minimize cost to Doraemon and maximize benefit to Doraemon by asking and using yes/no question.

b. Generosity maxim

The utterances of generosity maxim found in cartoon movie of Stand By Me Doraemon is among others as follows.

1. Noby : can I borrow your tool, Doraemon?

Doraemon : i'm not sure you can.

2. Big G : You can play ball with us today. Be thankful.

3. Noby : I owe everything to you.

In the utterance (1) Noby maximizes benefit to him and he he requested to doraemon politely. The utterance (2) tells about negatif maxim (impolite). Big G is ought to say i can invite you to play ball with us. Utterance (3) tells about Noby minimize the benefit to him and maximize cost to self. He need Doraemon as his friend.

c. Approbation maxim

The utterances of approbation maxim found in cartoon movie of Stand by Me Doraemon are among others as follow.

1. Doraemon: She's pretty.

Noby : You think so?

2. Noby : That's great!

3. Noby : He's impressive

4. Noby : She's so pretty.

5. Doraemon:This is awesome!!

Noby : Thank you, Doraemon.

6. Noby : Are you okay, Shizuka?

Sizhuka :You're wonderful, Noby!

In utterance (1) Doraemon gives approbation to Sizhuka because she looks very beautiful. The utterance is uttered when Noby and go to Sizhuka's house. In utterance (2) Noby gives approbation to Doraemon's tool. He is very proud of having Doraemon in his life. In utterance (3) Noby gives his approbation to Ace because he is very smart and handsome student in his class. Utterance (4) Noby gives his praise to Sizhuka because he thinks that she is very beautiful girl ever had. Utterance (5) tells that Doraemon is really appreciate of what have Noby done. Utterance (6) Shizuka is very happy saved by Noby. She gives approbation to Noby. 
d. Modesty maxim

The utterances of modesty maxim found in cartoon movie of Stand By Me Doraemon are among others as follows.

1. Noby : I've never had anything so good.

Future Noby : Great-great grandpa,

In the utterance (1) Noby (maximizes self-dispraise to himself by saying his ability.

e. Agreement maxim

The utterances of agreement maxim found in cartoon movie of Stand By Me Doraemon are as follows.

1. Sizhuka :It's dangerous up here.

Noby : You're right.

2. Doraemon : she is pretty

Noby : yes, sure

Utterance (1) means that Noby is agree with Sizhuka's opinion about the weather in the mount. In utterance (2) Noby agree with Doraemon's opinion about Shizuka.

f. Sympathy maxim

The utterances of sympathy maxim found in cartoon movie of Stand By Me Doraemon are as follows.

1. Big. $\mathrm{G}$ : Give him a break. He's been standing forever and he's tired.

2. Teacher : I'm sorry. At this rate, you'll flunk elementary school.

3. Doraemon :What's grown-up Noby doing? In bed with a cold. Sizhuka : Oh, man. I'm sorry to hear that

In utterance (1) Big G minimize antipathy to other (Noby) and He maximize sympathy to other (Noby). In utterance (2) explains about teacher's sympathy to Noby's score in the class. In utterance (3) Sizhuka gives her simpathy to Noby because Noby was sick and she doesn't know before.

\section{Politeness scale by Robin Lakoff}

a. Formality

1.Noby : Excuse me, i'm so sorry sir im late.

2.Noby : I'm sorry I'm late again sir! 
Utterance (1) tells about Noby's formality word to speak with his teacher. He speak formally to say sorry because of his late. In utterance (2) Noby says sorry for his late in his wedding party.

b. Hesitancy

1. Noby :Start working! Please!

2. Shizuka:Sketchbook, please?

3. Doraemon:Please! You have to put her back!

4. Noby : Go! This memory!

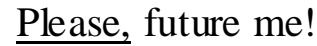

In utterance 1-5 all the words uses word please to say something. It means that the characters of the film uses hesitancy in maxim.

c. Equality

1. Big G : Noby! Nice catch!

2. Doraemon : Will you clean the living room now? Noby : Okay!

3. Noby : Shizuka! Can I talk to you?

Shizuka : Sure.

In utterance 1-3 means that all the words used to act as though they are in the same level or equal. It means that Noby, shizuka, Big G and Doraemon are friend and in the same level.

\section{CONCLUSION}

After analyzing the data taken from the utterances in cartoon movie of Stand By Me Doraemon, the researcher took a conclusion about the use of politeness principle in cartoon movie of Stand By Me Doraemon, there are six maxims of politeness principle applied; they are as follows: tact maxim, generosity maxim, approbation maxim, modesty maxim, agreement maxim, sympathy maxim and formality, hesitancy, and equality scale. In this research paper, the researcher focuses on the use of politeness principle and scale found in the data.

The researcher found the use of politeness principle in cartoon movie of Stand By Me Doraemon they are 25 politeness principle found in the movie. 1 tact maxim, 3 generosity maxim, 6 approbation maxim, 1 modesty maxim, 2 agreement maxim, 3 sympathy maxim, 2 formality scale, 4 hesitancy scale, and 3 equality scale. Approbation maxim is the maxim of the most numerous in the movie "Stand By Me Doraemon" this is because the characters in this film seeks to avoid conflict and create an environment that is comfortable in a communication. From the above analysis it can be concluded that the use of utterances 
manners in a very important conversation. This is because to create a comfortable atmosphere in the conversation so that both the speaker and the hearer no one feels offended or there was a misunderstanding in improved communications.

\section{SUGGESTION}

Based on the analysis and conclusion of the research, the researcher would like to give some suggestions about the analysis of dialogs in movie stand by me Doraemon using pragmatics approach particularly on politeness principle based on Leech and Lakoff. There are many occasions where people employ politeness principle. Therefore, it is recommended that the other researchers analyze the same point of view about politeness principle and its factors influencing the use of the pragmatics politeness strategy, but they may look at it from different kind of angle e.g. the analysis of politeness strategy in other literary works such as novel, folklore, conversation, news, etc.

Besides analyzing the same point of view about Politeness principle based on Leech and Lakoff and its factors influencing the use of the politeness principle from a different kind of angle, it is suggested that other researchers also pay intention in combining those politeness principle above with other issues, for example the use of politeness principle by children.

\section{REFERENCES}

Essays, UK. (2013). The Effects Of Using Cartoon Videos English Language Essay. Retrieved from http://www.ukessays.com/essays/english-language/the-effects-ofusing-cartoon-videos-english-language-essay.php?cref $=1$.

Grundy, P. (1995). Doing pragmatics. London: Edward Arnold.

Handayani, Mira. (2011). The analysis of politeness strategies used by the characters in the film of Ugly Truth. Thesis: English Letter Department Faculty of Adab and Humanities, State Islamic University Syarif Hidayatullah. Jakarta.

Ismet, M., Nawir. (2014). Aspek Sopan Santun Ujaran Dalam Film Eat Pray Love karya Ryan Murphy. Published in Fakultas Ilmu Budaya Universitas Sam Ratulangi. Ratulangi.

Krisnoni. (2013). Politeness Strategies used in Request by the Characters in Inception Movie”. Thesis published in Department of Language Studies Graduate Program Muhammadiyah University of Surakarta. Surakarta.

Leech, Geoffrey. (1983). Principles of Pragmatics. New York: Longman Group Limited. 
Levinson, Stephen C. (1983). Pragmatics. Cambridge: Cambridge University Press.

Pande, Ramakumara. (2008). Nepalase Cartoons: Himalayan Humour Sense of Humour Series Michigan: Universitas Michigan. Ratna Pustaka Bandar, 4 September 2008. Tebal 94 Halaman. Retrieved on May 2012. http://books.google.co.id/books?idnature + of +cartoon.

Rahardi, Kunjana. (2005). Pragmatik: Kesantunan Imperatif Bahasa Indonesia. Jakarta: Penerbit Erlangga.

Septyaningsih, Ani. (2007). An analysis of positive politeness Strategy in the film entitled "in good company" (a pragmatics study).Published in Faculty Of Letters and Fine Arts Sebelas Maret University Surakarta. Surakarta.

Sinkeviciute, Valerija. (2010). A Comparative Analysis of Politeness in First Encounter Conversations in British English Film and Peninsular Spanish Film. Published in Department of English Philology. Vilnius University. Lithuania.

Thomas, Jenny. (1995). Meaning in Interaction: an Introduction to Pragmatics. London and New York: Longman.

Titi, Pujiasih (2007). Teaching Names of Object Using a Cartoon Movie Entitled "Dora the Explorer" For Six grade Students of Elementary School (A Case Study of The Sixth Grade Students of SD Negeri 05 Randudongkal). Skripsi. Semarang: Universitas Negeri Semarang. Retrieved on November 2011. http://.pdf-finder.com.CARTOONMOVIE-html.

Wardhaugh, Ronald. (1977). Introduction to Linguistics. New Jersey: Mc Graw-Hill Book Company.

Wijana,Putu Dewa. (1996). Dasar-Dasar Pragmatik. Yogyakarta. Andi Press.

Yule, George. (1996). Pragmatics. New York: Oxford University Press. 